\title{
Effects of land use practices on soil organic carbon, nitrogen and phosphorus in river Nzoia drainage basin, Kenya
}

\author{
Wabusya Moses ${ }^{1}$, Humphrey Nyongesa ${ }^{2}$, Martha Konje ${ }^{3}$, Humphrey Agevi ${ }^{3}$, Mugatsia Tsingalia ${ }^{1}$ \\ ${ }^{1}$ Department of Biological Sciences, Moi University, Eldoret, Kenya \\ ${ }^{2}$ Department of Sugar Technology, Masinde Muliro University of Science and Technology, Kakamega, Kenya \\ ${ }^{3}$ Department of Biological Sciences, Masinde Muliro University of Science and Technology, Kakamega, Kenya
}

Email address:

mugatsi2005@ygmail.com (M. Tsingalia),wabusyam@yahoo.com (W. Moses)

\section{To cite this article:}

Wabusya Moses, Humphrey Nyongesa, Martha Konje, Humphrey Agevi, Mugatsia Tsingalia. Effects of Land use Practices on Soil Organic Carbon, Nitrogen and Phosphorus in River Nzoia Drainage Basin, Kenya. Agriculture, Forestry and Fisheries.

Vol. 4, No. 4, 2015, pp. 153-158. doi: 10.11648/j.aff.20150404.11

\begin{abstract}
Land use activities along River Nzoia Drainage Basin, Kenya, include cultivation along the river banks, over grazing, deforestation, draining of wetlands for horticulture, harvesting of sand and brick-making. These activities have brought about changes in soil properties in the drainage basin adversely affecting farming output and the ecosystem in general. Consequently, it is important to understand how the different land use activities influence the soil properties in order to design and implement effective soil management strategies. This study examined the effects of land use practices on selected soil nutrients in Nzoia River Drainage Basin in Bungoma County. Cultivation and grazing were identified as important land use practices, while undisturbed sites were treated as controls. Land use practices along the river were identified by actual surveying of the study area. Secondary data on land use practices were obtained from technical reports, from local authorities and government offices. Soil samples were collected from different land use areas using randomly placed $5 \mathrm{mx} 5 \mathrm{~m}$ quadrats. Solis were collected at depths of $15 \mathrm{~cm}$ in zigzag grid layout in each sample quadrat using soil auger. A total of 72 soil samples were collected in the study sites and analyzed for total nitrogen $(\mathrm{N})$, available phosphorus $(\mathrm{P})$ and organic carbon $(\mathrm{C})$. Analysis of variance and correlation were performed to determine the significant land use practices affecting soil N, C and P. Cultivation had a significant effect on soil organic $\mathrm{C}$ mean value of 1.91 but negatively correlated with total Nitrogen and soil $\mathrm{C}$ while undisturbed sites exhibited positive correlation with $\mathrm{C}(P \leq 0.05)$. On the basis of our findings, it is recommended that conservation agriculture be practiced in the River Nzoia and its drainage system.
\end{abstract}

Keywords: Cultivation, Grazing, Organic Carbon, Nitrogen, Phosphorus, Conservation Agriculture

\section{Introduction}

Land-use changes are widely recognized as key drivers of global carbon dynamics [13, 29] and grasslands have received much attention for their substantial potential to act as carbon sinks in the recent past $(4,7,9,21,23]$. With improved management practices, such as soil fertilization, promotion of native vegetation, sowing of legumes and replanting perennial grasses, most grasslands worldwide are considered to be important carbon sinks [12]. However, overgrazing and poor pasture management have led to significant losses of carbon from soils [6, 10, and 11]. Deforestation causes increased losses of carbon, nitrogen, phosphorus, and sulphur from terrestrial ecosystems. Where deforestation is followed by conversion to other land uses, the effects of deforestation are magnified. The major causes of organic carbon losses are harvesting and burning of forest residues, accelerated decomposition, decreased production of wood and roots, and erosion. Nitrogen and sulphur are lost through the same pathways, and additionally by leaching to stream- and ground-water, and by the anaerobic production of nitrogen and sulphur containing gases. Phosphorus is lost primarily through harvest and erosion. More than half of the carbon and nitrogen and somewhat less phosphorus and sulphur can be lost in sites where forests are converted to other uses [16]. Losses of these elements following deforestation are most rapid in sites with high decomposition rates, especially in the tropics and on fertile soils. The 
interactions of the carbon, nitrogen, phosphorus, and sulphur cycles affect losses of any element through nutrient limitations to biological transformations, ratios of element availability, which cause either biological mobilization or immobilization, and anion/anion interactions in the soil solution [16].

Intensified cultivation practices often lead to widespread increases in the levels of nitrogen and phosphorous in lowland watercourses resulting in subsequent nuisance growths of algae and other aquatic plants [3]. In New Zealand for instance, the introduction of nitrogen fixing clovers, use of nitrogen fertilisers, including the practice of spreading animal wastes on pastures, and direct addition of stock urine and faeces in pasture have increased the amounts of nitrate leaching from pastoral catchments [3].

Reduction in vegetation cover reduces the amount of soil organic carbon in the soil. Soil organic carbon has been shown to be adequate in forest and bush lands in the upper zones but deficient in the lower zones which was attributed to the reduced plant cover and high rate of decomposition and mineralization of organic matter in the lower zones [17]. The results also showed that soil organic carbon was higher in annual crops, pasture and fallow as a result of the addition of farmyard manure or use of inorganic fertilizers.

Livestock grazing has been proposed to be the greatest source of riparian habitat degradation [25]. Cattle consume streamside vegetation, disturb soils, destabilise stream banks, and churn up channel sediments, and deposit manure and urine. Livestock damage to riparian vegetation and soils destabilizes the banks and lead to mobilization of fine sediments that in turn cause sedimentation in the channel and reduced stream clarity [26]. In addition, more runoff of sediments occurs from soil disturbed and compacted by livestock trampling [18]. The resulting increased sediment load is accompanied by particular nutrients that may contribute to stream enrichment as well as eutrophication of lakes and estuaries downstream (e.g., 15, 27] estimated that bank erosion contributed $32 \%$ of sediment discharge and $10 \%$ to the export of phosphorus from agriculture catchments in Canada.

A study on the effects of increasing grazing pressure on soil carbon and nitrogen storage in temperate grasslands of northern China revealed that carbon and nitrogen storage in both $0-10 \mathrm{~cm}$ and $10-30 \mathrm{~cm}$ soil layers decreased linearly with increasing stocking rate [30]. Carbon storage in the $0-10 \mathrm{~cm}$ soil layer was significantly higher in lightly grazed than in heavily grazed grasslands after a five year grazing treatment. Their findings suggest that there is an underlying transformation from soil carbon sequestration under light grazing to carbon loss under heavy grazing. It was demonstrated that grazing increased the bulk density and moisture content through compaction and exposure of the soil to the sun, but reduced most soil nutrients through feeding and subsequent erosion due to the reduced ground cover [30].

This study sought to determine the effects of land use practices on soil organic Carbon and total Nitrogen in the
Nzoia River Drainage Basin. The current agricultural practices that involve deliberately maintaining ecosystems in a highly simplified, disturbed, and nutrient rich state by supplying limiting factors, especially water, mineral nitrogen, and mineral phosphate in excess and active control of pests in order to maximise production turns is a major problem of nutrient management in Nzoia River Drainage Basin. There is therefore the need to reclaim the soils and improve on its properties in order to increase agricultural productivity in the Nzoia River Drainage Basin in Bungoma County.

\section{Materials and Methods}

\subsection{Study Site}

Nzoia River Basin lies between latitudes $1030^{\prime} \mathrm{N}$ and 00 $05^{\prime} \mathrm{S}$ longitudes $340^{\prime} \mathrm{W}$ and $3545^{\prime} \mathrm{E}$. The Nzoia River originates from the Cherengani Hills at a mean elevation of $2300 \mathrm{~m}$ above sea level and drains into Lake Victoria at an altitude of $1000 \mathrm{~m}$ [19]. It runs approximately south-west and measures about $334 \mathrm{~km}$ with a catchment area of about $12,900 \mathrm{~km}^{2}$, with a mean annual discharge of $17777 \times 106 \mathrm{~m}^{3}$ year. The study site in Bungoma East sub county extended between longitudes $34^{\circ} 34^{\prime} 00^{\prime \prime}$ to $34^{\circ} 51^{\prime} 30^{\prime \prime} \mathrm{E}$ and latitudes $0^{\circ} 23^{\prime} 00^{\prime \prime}$ to $0^{\circ} 37^{\prime} 30^{\prime \prime} \mathrm{N}$. The climate of the basin is mainly tropical humid characterised by the day temperatures varying between $16^{\circ} \mathrm{C}$ in the highland areas of Cherengani and $\mathrm{Mt}$ Elgon to $28^{\circ} \mathrm{C}$ in the lower semi-arid areas on annual basis. The mean annual night temperatures vary between $4^{0} \mathrm{C}$ in the highland areas to $16^{\circ} \mathrm{C}$ in the semi-arid areas. Mean annual rainfall varies from a maximum of 1100 to $2700 \mathrm{~mm}$ and a minimum of 600 to $1100 \mathrm{~mm}$. The area experiences four seasons in a year as a result of inter-tropical convergence zone. There are two rainy seasons, namely, short rains (October to December) and the long rains (March and May) and two dry seasons (If I understand well, is this rearrangement correct?). The dry seasons occur in the months of January to February and June to September ([19].

Among the main features in the area are the Nzoia Sugar Company plantations, Malava Forests, the Nandi Escarpment, and the Pan Paper Milling Factory at Webuye [19]. The riparian communities engage in sugarcane agriculture, fishing and livestock keeping along with subsistence farming of maize, beans, sweet potatoes and cassava. Three main sites, Kakimanyi, Nambalayi and Kuywa were sampled in the study area. Grazing and horticulture were the main land use practices while certain areas that were undisturbed (without any land use practice), were treated as control sites during the study.

\subsection{Land Use Practices Data}

Primary data was obtained through actual survey and mapping of the study area to identify the land use practices. Secondary data on land use practices was obtained from research technical reports by the Nzoia River Basin Management Initiative and local and government authorities such as Webuye District Agricultural offices. 


\subsection{Soil Collection and Analysis}

Soil samples were randomly collected at depths of $0-15 \mathrm{~cm}$ in a zigzag grid layout using an auger across the sample plots of $5 \mathrm{~m} \times 5 \mathrm{~m}$ in study sites under different land use practices during rain and dry seasons. The individual samples of soil were bulked and mixed thoroughly in buckets. A total of 72 soil sub samples were obtained from the bulks and packed in clear labelled plastic bags. The samples were placed in cooler boxes with ice for transportation to the laboratory. The samples were air-dried, ground to pass through a 2-mm mesh sieve for nitrogen, phosphorus and carbon analyses. Soil total nitrogen was determined by semi micro-Kjedal digestion method where $4.4 \mathrm{ml}$ of the digestion mixture (selenium, lithium sulphate, hydrogen peroxide and concentrated sulphuric acid) was added to $0.3 \mathrm{~g}$ soil and digested for two hours at $360^{\circ} \mathrm{C}$. Later, $25 \mathrm{ml}$ of distilled water was added, the solution cooled and aliquot of $5 \mathrm{ml}$ taken for distillation for total nitrogen. Another aliquot of $5 \mathrm{ml}$ was taken and available phosphorus determined by spectrophotometer method at wavelength $880 \mathrm{~nm}$ as described by [20]. Total organic carbon was determined by oxidizing $0.3 \mathrm{~g}$ of soil with a solution of $5 \mathrm{ml}$ of $0.0667 \mathrm{M}$ potassium dichromate and
$7.5 \mathrm{ml}$ of concentrated sulphuric acid in the digestion block. The concentration of potassium dichromate remaining after digestion was titrated with $0.033 \mathrm{M}$ ferrous ammonium sulphate as described by [20]. Analysis of variance (ANOVA), with the aid of General Linear Model, and correlation analysis were performed between land use practices and soil nutrients using SAS software to determine the significant land use practices on soil nitrogen, phosphorus and carbon soils were randomly collected in study sites based on the land use practices using a randomized block design. .

\section{Results}

Figs 1, 2, and 3 show the levels of soil nutrients in the different sites of the study area under different land use practices. In all the study sites, total soil organic carbon was highest in areas that were undisturbed followed by areas that were under intense grazing (Fig. 1). Total nitrogen on the other hand differed both by study site and land use practice being highest in land under grazing, especially in Kuywa (Fig. 2). Phosphorus differed at different study sites under different land use practices without showing any specific pattern (Fig $3)$.

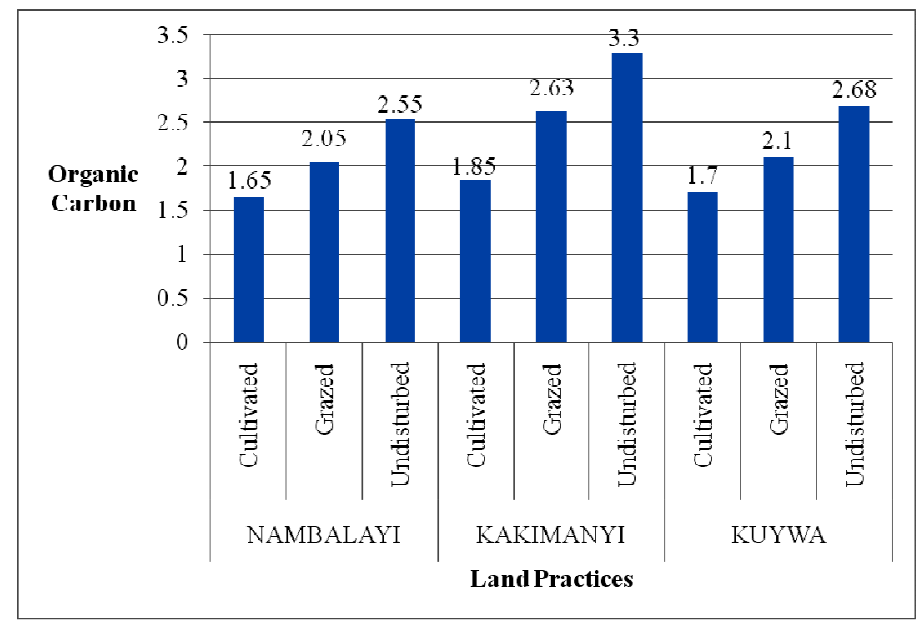

Figure 1. Levels of total soil organic carbon in various study sites with different land use practice.

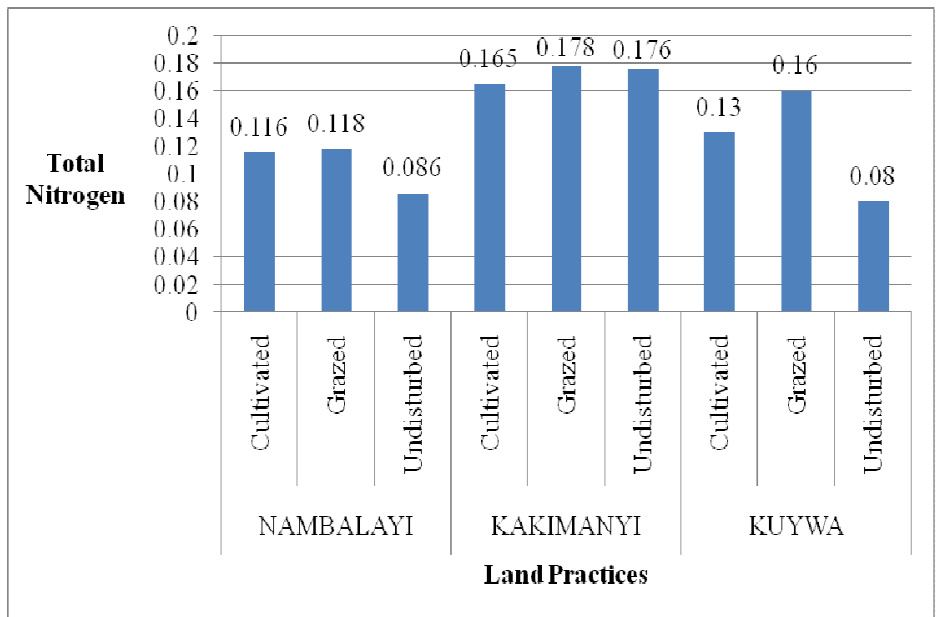

Figure 2. Levels of total soil nitrogen in various study sites with different land use practice. 


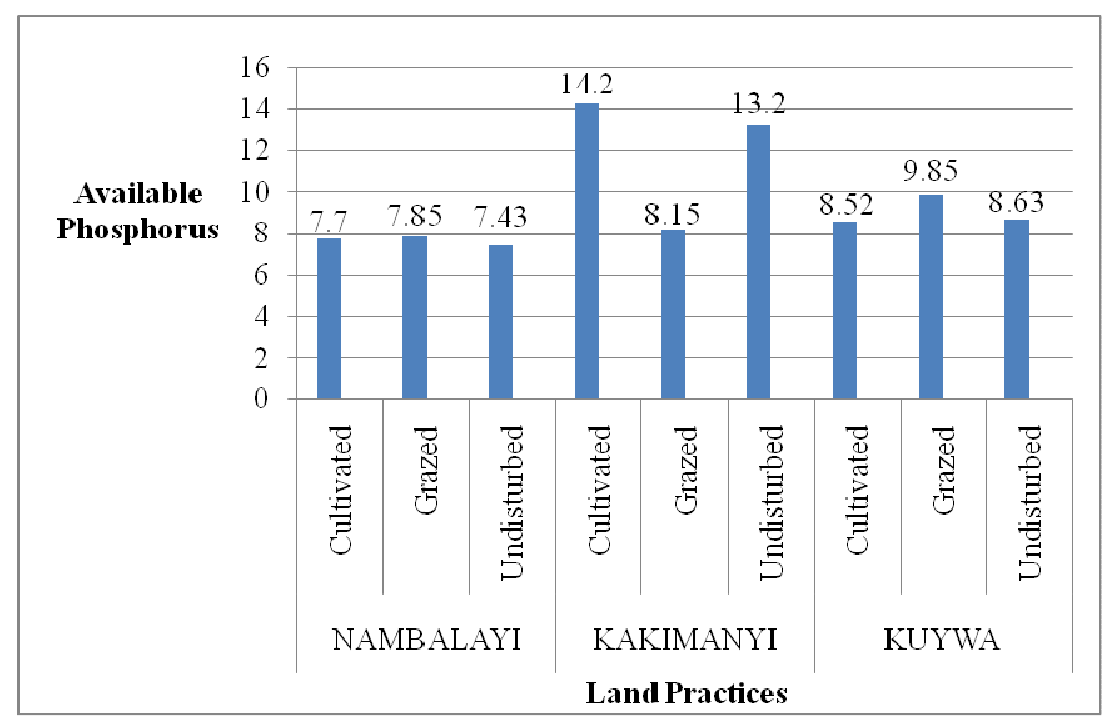

Figure 3. Levels of available soil phosphorus in various study sites with different land use practice.

Selected results of ANOVA are shown in table 1. These results clearly show that cultivation significantly decreased soil organic $\mathrm{C}$.

Table 1. Effects of land use practices on the mean soil total nitrogen $(N)$, available phosphorus $(P)$ and carbon $(C)$ in the River Nzoia Drainage Basin. Means followed by different letters within a row are significantly different (ANOVA; $P \leq 0.05$ ).

\begin{tabular}{llll}
\hline Land use practice & Total N \% & Available P ppm & Organic C \% \\
\hline Grazed & $1.64 \mathrm{a}$ & $2.60 \mathrm{a}$ & $1.97 \mathrm{a}$ \\
Cultivated & $1.64 \mathrm{a}$ & $2.66 \mathrm{a}$ & $1.91 \mathrm{~b}$ \\
Undisturbed & $1.64 \mathrm{a}$ & $2.69 \mathrm{a}$ & $1.99 \mathrm{a}$ \\
\hline
\end{tabular}

There were no significant differences between grazed and undisturbed sites for total nitrogen and phosphorus $(P>0.05)$. Similarly, cultivation did not significantly affect $\mathrm{N}$ and $(P>$ $0.05)$.

At significant level of $P \leq 0.05)$ undisturbed sites positively correlated with soil organic carbon $(\mathrm{r}=0.50785 ; \mathrm{p}=0.0001)$. In addition, cultivation negatively correlated with total $\mathrm{N}$ and soil organic carbon $(\mathrm{r}=-0.29010$ and $P=0.0222$; and $\mathrm{r}=-$ 0.41052 and $P=0.0009$ respectively).

Table 2. Pearson Correlation Coefficients between land use practices and soil nutrients (number in parenthesis is the probability (P)-value).

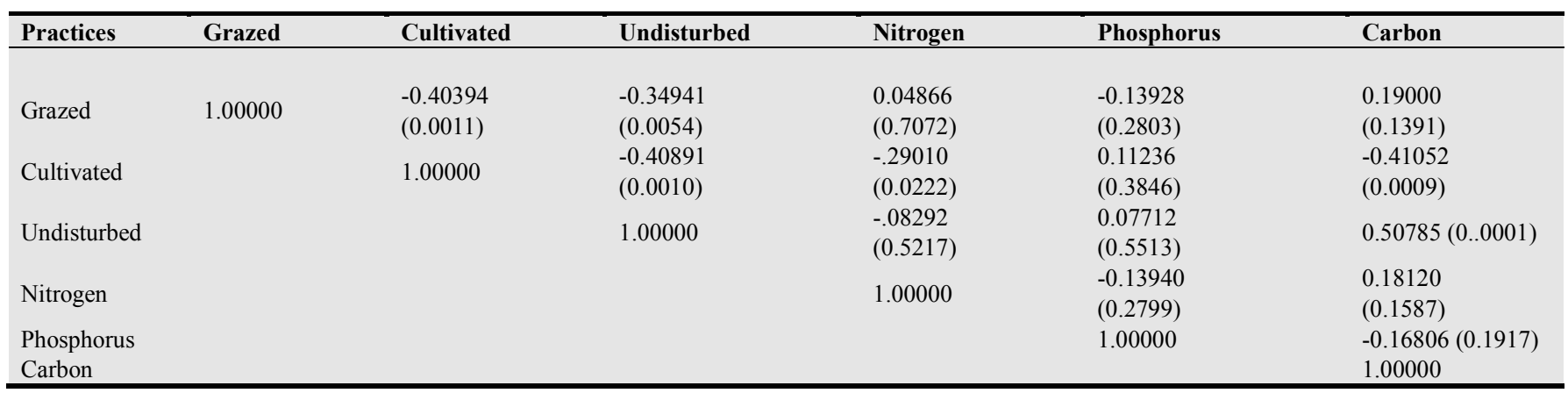

\section{Discussion}

\subsection{Land Use Practices}

The observed land use practices in the study area are attributed to residents in these areas who rely on farming for both commercial and subsistence reasons. The other reason is the existence of the two sugar industries (Nzoia Sugar Company and Mumias Sugar Company) and the Webuye maize milling plant. These industries have encouraged farmers to cultivate more sugar canes and maize so as to earn a better living. Undisturbed areas have been preserved for purpose of cultural practices especially circumcision.

\subsection{Cultivation and Soil Organic Carbon}

Correlation between land use practices and soil organic Carbon was negative $(r=-0.44, \mathrm{P}=0.0004)$. This is probably because under heavy cultivation practices, the soil is broken and highly churned thus improving the aeration. It also exposes soil organic matter to micro-organisms that later on enhances decomposition of soil organic matter hence a decline in soil organic carbon. More so, the crops in cultivated areas are usually harvested by removing both the fruit and the foliage which finally leads low addition of organic matter levels and hence a decline in soil organic carbon [29].

Studies by [14] demonstrated a decline in soil organic 
carbon over time while trying to compare the conversion of land from grass land to arable cultivation land. Studies by [1] have shown that the highest carbon stocks are found in natural forest, artificial forest and artificial grassland ecosystems, and that continuous cropping reduced carbon stock by about $70 \%$.

Table 3. Standard levels of Soil Nutrients (N, P and C) [20] .

\begin{tabular}{lll}
\hline ORGANIC CARBON & TOTAL NITROGEN & AVAILABLE PHOSPHORUS \\
\hline$>3.0$ High & $>0.25$ very high & \\
$1.5-3.0$ moderate & $0.125-0.25$ moderate & $<10$ ppm very low \\
$0.5-1.5$ low & $0.05-0.125$ low & \\
$<0.5$ very low & $<0.05$ very low & \\
\hline
\end{tabular}

Grazing did not have any significant effect on soil N, P and C. This contradicts the findings by other researchers that have shown that grazing depresses soil organic carbon content and storage [24 and 28]. It has been demonstrated that there is a range of potential indirect mechanisms through which soil carbon may be affected by increased grazing $[2,5$, and 22]. It appears that grazing depresses soil organic carbon storage through reducing plant biomass especially by removal of palatable grasses and sedges that built soil carbon pools. Palatable plant species generally produce litter of high quality for decomposers than do unpalatable species [9]. The results of our findings can be attributed to the system of grazing that is practiced in the basin. Grazing is small scale with very few animals as most farmers prefer the cultivation of maize and sugar cane to rearing of livestock. Secondly most of their grazing grounds are usually used for growing some crops that are harvested after a short season.

The total Nitrogen and available Phosphorus were selectively affected by the land use practices. Cultivated and grazed sites had higher total $\mathrm{N}$ unlike undisturbed sites. This fact takes place probably because of the chemical and organic fertilizers used, waste products such as dung and urine from animals [3].

\section{Conclusions and Recommendations}

In conclusion, cultivation and fallow demonstrate an inverse significant influence of the soil carbon. Whereas cultivation reduced soil carbon, leaving the land under fallow increased the soil carbon. Soil nitrogen and phosphorus were unaffected by land use practices point to their resilience to land use changes. In all the study sites, available phosphorus was below the standard levels [20] except in one study site (Kakimanyi) where the levels were higher under cultivation and undisturbed sites. Organic carbon and nitrogen were moderately high in all the study sites under different land use practices.

On the basis of our findings, we recommend that conservation agriculture be practiced in the River Nzoia Basin and its drainage system. Interspersing different land use practices can help in recovery of nitrogen, carbon and phosphorus. On the basis of the effects on the three nutrients studied, grazing and fallow are recommended as the preferred land use practices because of their minimal effects It is also recommended that more studies need to be carried out given the extensive nature of the Nzoia River Basin.

\section{References}

[1] Anikwe M. (2010) Carbon storage in soils of South-eastern Nigeria under different management practices. Carbon Balance and Management 5:5

[2] Bardgett R.D., and Wardle D.A. (2003) Herbivore-mediated linkages between aboveground and below ground communities. Ecology, 84: 2258-2268.

[3] Baudry J. and Thenail, C. (2003) Instit National de la Recherché Cedex, France. Last accessed 9/24/014.

[4] Conant R T, Paustian K, Elliott E T, 2001. Grassland management and conversion into grassland: Effects on soil carbon. Ecological Applications, 11: 343-355.

[5] De Deyn, G.B., Cornelissen, J.H.C. and Bardgett, R.D. 2008. Plant functional traits and soil carbon sequestration in contrasting biomes. Ecology Letters, 11, 516-531.oration of (?)

[6] Elmore A J, Asner G P, 2006. Effects of grazing intensity on soil carbon stocks following deforestation of a Hawaiian dry tropical forest. Global Change Biology, 12: 1761-1772.

[7] Fang J Y, Guo Z D, Piao S L et al., 2007. Terrestrial vegetation carbon sinks in China. Science in China (Series D), 50: 1341-1350

[8] Grime J.P., Cornelissen J.H.C., Thompson K. and Hodgson J.G.(1996): Evidence of a causal connection between antiherbivore defence and the decomposition rate of leaves. Oikos, 77: 489-494.

[9] Guo L B, Gifford R M, 2002. Soil carbon stocks and land use change: A meta-analysis. Global Change Biology, 8: 345-360.

[10] He N P, Yu Q, Wu L et al., 2008. Carbon and nitrogen store and storage potential as affected by land-use in a Leymus chinenis grassland of northern China. Soil Biology \& Biochemistry, 40: 2952-2959.

[11] He N P, Zhang Y H, Yu Q et al., 2011. Grazing intensity impacts soil carbon and nitrogen storage of continental steppe. Ecosphere, 2, art8, doi:10.1890/ES1810-00017.00011.

[12] Jones M B, Donnelly A, 2004. Carbon sequestration in temperate grassland ecosystems and the influence of management climate and elevated $\mathrm{CO} 2$. New Phytologist, 164: 423-439.

[13] IPCC (Intergovernmental Panel on Climate Change), 2007. Fourth Assessment Report, Climate Change 2007: Synthesis Report. Cambridge, UK: Cambridge University Press. 
[14] Johnson A. E, Poulton P. R, and Coleman K. (2009) Soil organic matter: Its importance in sustainable agriculture and carbon dioxide fluxes. Advances in Agronomy 101, 1-57

[15] Kondolf G. M, Piegay and N. landon (2007). Changes since 1830 in riparian zone of the lower eygues river. France landscape Ecology 22:367-384

[16] Lobe J. (2004). "Hamburger Consumption Spurs Amazon Deforestation" Common Dreams (http://www.commondreams.org/headlines04/0409- 05.htm) Last accessed 8/29/014.

[17] Mehlich A, Bellis E, and Gitau J.K (1964) Fertilizing and liming in relation to soil chemical properties. Scott Laboratories, Department of Agriculture, Nairobi.

[18] Nguyen M. L; Sheath G W; Cooper A b (1998) Impact of cattle treading on hill land 2 Soil physical properties and contaminant runoff. Newzealand journal of agricultural Research 41:279-290

[19] Nzoia River Basin Management Initiative Technical Report (2006-2011). A public private partnership between Water Resources Management Authorities and Civil Societies, Learning Institutions and Communities. pp.24.

[20] Okalebo, J.R., K.W. Gathua, and P.L. Woomer. (1993). Laboratory Methods of Soil and Plant Analyses: A Working Manual. Technical Publication, no. 1. Nairobi,

[21] Post W M, Kwon K C, 2000. Soil carbon sequestration and land-use change: Processes and potential. Global Change Biology, 6: 317-327.

[22] Semmartin M., Bella C.D., and de Salamone I.G. (2010): Grazing-induced changes in plant species composition affect plant and soil properties of grassland mesocosms. Plant and Soil, 328: 471-481.
[23] Soussana J F, Loiseau P, Vuichard N et al., 2004. Carbon cycling and sequestration opportunities in temperate grasslands. Soil Use and Management, 20: 219-230.

[24] Snyman H.A., and Du Preez C.C. (2005) Rangeland degradation in a semi-arid South Africa-II: influence on soil quality. Journal of Arid Environments, 60: 483-507.

[25] Trimble S. W. (1994) Stream channel erosion and change Resulting from riparian forests. Geology 25:467-469.

[26] Waters T. F. (1995) Sediment in streams. American Fisheries Society Monograph 7. American Fisheries Society, Bethesda, Maryland, $251 \mathrm{pp}$.

[27] Williamson, M. (1996) Biological Invasions. Chapman and Hall, London

[28] Wu G.L., Liu Z.H., Zhang L., Chen J.M. and Hu T.M. (2010). Long-term fencing improved soil properties and soil organic carbon storage in an alpine swamp meadow of western China. Plant and Soil, vol.332: 331-337.

[29] Yang Y S, Xie J S, Sheng H et al., 2009. The impact of land use/cover change on storage and quality of soil organic carbon in mid-subtropical mountainous area of southern China. Journal of Geographical Sciences, 19:49-57.

[30] Zhang Y. H, Yu Q, Chen Q. S, Pan Q. M, Zhang G. M and Han X. G (2011).Grazing intensity impacts soil carbon and nitrogen storage of continental steppe. Ecosphere www.esajournals.org 2(1): art 8. Pp. 1- 8 